\title{
A LAWYER'S VIEW OF THE ADVANTAGES OF UNIFORMITY IN ACCOUNTING
}

\author{
AIAN N. POLASKY* \\ Many ... expressions in accounting need explanation and clarification .... . \\ Until the profession deals with all these matters satisfactorily, first for itself and \\ then for understanding by the consumer of its product, there will continue to be an \\ awkward failure of communication in a field where clear communication is vital. \\ Special Comm. on Opinions of the Accounting Principles \\ BoARd, AICPA, REPORT I5 (1965).
}

\section{INTRODUCTION}

The excerpted statement highlights a major aspect of the lawyer's approach to the utility of accounting presentations in his professional activity. Both the law and the lawyer depend upon effective communication. And, in increasing degree, the necessary communication involves the terminology and financial determinations of the accountant.

Law depends on Accounting, the Art, for assistance in the development of data for the wise regulation of economic affairs and for terminology in prescribing the type of regulation deemed appropriate. The lawyer, in his professional capacity, uses the language of accounting in prescribing the result sought by a dispositive or contractual document; he finds an understanding of accounting necessary in interpreting private agreements or legislation utilizing accounting terminology; and he relies upon accounting determinations in effectuating the legislative or privately drafted mandate using accounting terminology or in presenting a client's position with respect to a formula employing accounting terminology. To the extent that the accounting terminology and presentations prove ambiguous or otherwise inadequate, the lawyer-draftsman can only use them as a point of departure in more accurately expressing the meaning sought to be conveyed; and, similarly, lack of specificity broadens the area of dispute that he faces in his role as an advocate.

An evaluation of the lawyer's view of the relative disadvantages of lack of uniformity suggests, however, a bit of perspective about lawyers and their experiences with accounting data. Judge Friendly has suggested that, "Accounting concepts are a foreign language to some lawyers in almost all cases, and to almost all lawyers in some cases." It might be added that lawyers are not a fungible commodity and that

- B.S.C. 1947, J.D. I951, State University of Iowa. Professor of Law, University of Michigan; Certified Public Accountant, Iowa; member of the Iowa and Illinois bars; member, American Institutc of Certified Public Accountants (AICPA), American Accounting Ass'n, Michigan Society of CPAs; Chairman, Committee for Liaison with AICPA on Uniformity in Accounting Principles of the American Bar Association's Section of Real Property, Probate and Trust Law.

${ }^{1}$ United States v. Kovel, 296 F.2d 9r8, 922 (2d Cir. I96I). 
variances in an individual lawyer's familiarity with accounting and in the nature of his particular practice are quite likely to influence his attitude.

\section{A. General Attitudes}

Some lawyers, like other laymen, tend to regard accounting as an exact, if unexciting, science which automatically spews forth the single appropriate amount, whether it be the "worth" of a business or the results of operations, if accurate data is recorded "in accordance with generally accepted accounting principles." Wider exposure of practitioners in recent years to accounting training and their acquisition of an understanding of accounting in the course of practice tends to dispel the naiveté; but it may also substitute a measure of disillusionment with the Art. The lawyer now knows that he must go beyond the figures shown in the financial statements if comparison of several companies is involved. He also knows that in determining "cost" or "net income" as a basis for determining rights under a contract, utilization of the term "in accordance with generally accepted accounting principles" may fall short of the precision required. It should not be surprising, therefore, that some lawyers may think longingly of developments that would narrow choices among presently acceptable, alternative procedures.

Several aspects of the lawyer's own training and experience may tend, however, to modify both his occasional exasperation at the need for interpretation and any tendency to view a move toward uniformity as singularly desirable. Two of these, his attitude toward codification and his experience with legislation and regulatory agencies, may be noted by way of preface.

Lawyers have had broad experience with attempts at codification, ranging from (I) generalization designed merely to record the single, universally accepted approach or (2) generalization expanded to include a process of selecting the most common practice where variations exist, to (3) an attempt, going beyond generalization from existing practice, to specify what "ought" to be. Lawyers recognize, as does the accounting profession, that codification in terms of "ought" rather than "is" poses the imperative of initial agreement on fundamental postulates and goals ${ }^{2}$ and a reconciliation of these premises where they are not compatible. The arrival at a consensus by those charged with codification, assuming a representative group of well-intentioned, but philosophically differing, individuals often requires a process of compromise and adjustment that may not be totally compatible with any one of the differing views of what "ought" to be prescribed or with clear-cut specificity.

Even where the process is one of generalization, there is awareness of the danger of rigidification of "rules" where doubts exist with respect to the wisdom of the current practice. Changing circumstances and unforeseen or newly emerging problems require constant exceptions or interstitial interpolation that may not be wholly consistent with the general rule; and lack of internal consistency between various

\footnotetext{
${ }^{2}$ See Storey, Accounting Principles: $A A A$ and $A I C P A$, J. Accountancy, June I964, p. 47 , at 55 .
} 
rules requires choice between applicable principles or, perhaps, reliance on the very inconsistency to furnish needed flexibility. Clearly, the greater the attempted specificity and "one rule" approach, the more difficult the task and the greater danger that codification, if accomplished, may neither provide the optimum prescription nor the flexibility often required in a dynamic society.

Obviously the relative desirability of certainty versus flexibility can be reduced to no easy over-all generalization in any broad societal institution. From his own experience the lawyer knows that the relative desirability of certainty bulks larger in certain fields, such as contract and property law, than in others, such as tort liability. Even within a particular area, attitudes may vary between lawyers constantly engaged in advising clients as to future transactions and those whose practice casts them in the role of an advocate seeking effectuation of an appropriate result in a given case rather than predictability for purposes of counseling. These factors will surely be reflected in a lawyer's individual attitude toward the relative desirability of uniformity in accounting.

The lawyer's attitude will also be tinged by his view of the potential impact of uniformity, or lack thereof, on the courts, regulatory agencies, and legislation with which he is concerned. Will a narrowing of acceptable principles influence courts in interpreting the terminology used in dispositive or contractual documents or in corporate legislation and to what extent is this desirable? Will failure of the accounting profession to move in this direction trigger some vigorous reaction by the SEC, for example, which could have a significant effect upon the lawyer called upon to represent his client in securities work? May a movement toward uniformity have a significant impact on the attitudes of regulatory agencies, such as the FTC, FPC, ICC, and state regulatory agencies, to mention a few, ${ }^{3}$ and to what extent will this facilitate the lawyer's task and the societal goal underlying the particular legislation? To what extent can there be an effect on tax legislation and administration? And, conversely, what effect may tax fiat have upon the principles to be adopted ? $^{4}$

The lawyer recognizes that a host of complex factors are at work. A divergence between accepted accounting principles and the particular regulatory prescription of accounting method does not signify a conflict between accounting and law but only a determination, in many cases, that differing purposes are to be served by financial data. Administrative agencies charged with regulating similar companies in a given industry require a measure of uniformity in reporting for comparability of treat-

\footnotetext{
${ }^{8}$ For a view of the effects of regulatory accounting, see Anthony, Showdown on Accounting Principles, Harv. Bus. Rev., May-June 1963 , p. 99, at 105.

"For example, is it likely that an enthusiastic groundswell will develop for prescribing the use of a FIFO inventory method, to the exclusion of LIFO, so long as the latter is permitted for income tax purposes and while the tax regulations require use of LIFO in financial statements if that method is to be approved for tax purposes? Treas. Reg. $\$ 1.472-2$ (c) (1958). For that matter, Treas. Reg. $\$$ I.471-2 (1958) suggests the inventory method "( 1 ) ... must conform as nearly as may be to the best accounting practice in the trade or business, and (2) . . . must clearly reflect the income."

${ }^{5}$ Cf. Hills, Statement of Legal Concepts of Accounting, 36 Iowa L. REv. 198, 225-26 (1951).
} 
ment, despite approval of alternative treatments by accountants. It may be expected that legitimate differences will continue to exist, because of particular legislative goals and administrative expediency, despite any uniformity movement within the accounting profession. This is not to suggest that a movement toward uniformity will have no effect. Surely a re-examination of principles and a narrowing of alternatives may lead to evaluation of the reasonableness of the regulatory and legislative prescription, and perhaps, modification where appropriate in the light of legislative purpose. The lawyer will not, however, expect that a uniformity movement will result in immediate acceptance; experience calls to mind examples where agreement on accounting principles has brought about no such change, even where change seemed desirable in the light of the legislative purpose. ${ }^{6}$

\section{B. How Uniformity May Affect the Lawyer}

The lawyer's view of current limitations of accounting data extends far beyond considerations of uniformity. He should be vitally interested in the implications of increased recognition of price-level changes ${ }^{7}$ and recommendations for departure from existing practice, such as valuation of inventories at replacement value and recognition of gain or loss prior to sale. The particular inquiry here, however, is directed to a view of the advantages of "uniformity."

The term uniformity itself is not free of ambiguity. There may be a broad consensus that greater uniformity of "accounting principles" is desirable, ${ }^{10}$ but there are surely differences in view as to the extent ${ }^{11}$ and manner in which it should be sought, the timing and agency ${ }^{12}$ through which it is to be brought about, and the compulsoriness of the prescription. ${ }^{13}$ There may be agreement that there should be accord on basic "postulates" or concepts and that a set of "broad principles" should be formulated based upon the basic assumptions which further development of guidelines for application; $;^{14}$ and, at the other pole, it will be agreed that absolute uniformity is a "chimera-impossible to achieve."15 Yet where do "basic principles" leave off and "practices" designed to permit desirable flexibility for differing cir-

\footnotetext{
${ }^{\circ}$ E.g., INT. REv. CODE of I954, $\$ \$ 452,462$, dealing with prepaid income and reserves for estimated expenses, repealed by Act of June I5, I955, $\$$ I, 69 Stat. 134 .

"See generally Staff of the Accounting Research Division, AICPA, Reporting the Financial Effects of Price-Levet Changes (Accounting Research Study No. 6, 1963).

${ }^{8}$ See Robert T. Sprouse \& Muurice Moonitz, A Tentative Set of Broad Accounting Principles For Business ENTERPRIses 27 (AICPA Accounting Research Study No. 3, 1962).

'The meaning of "principles" is also not free from ambiguity. See Storey, supra note 2, at 50-5I.

${ }^{10}$ See Catlett, Controversy Over Uniformity of Accounting Principles, J. Accountancy, Dec. I964, p. 37; Powell, The Development of Accounting Principles, J. Accountancy, Sept. I964, p. 37, at 4r.

${ }_{11}$ Compare Catlett, supra note 10 , at 40 , with Fox, Useful Comparability in Financial Reporting, J. Accountancy, Dec. 1964, p. 44. See also Anthony, supra note 3, at roo-or.

${ }^{13}$ See Storey, supra note 2, at 53. Earlier studies are noted by Storey at 47.

${ }^{13}$ Compare Powell, supra note I0, at 39-40, with Anthony, supra note 3, at 105-06. See also Cary, The SEC and Accounting, J. Accountancy, Dec. 1963, p. 47.

It See Powell, supra note ro, at 38 .

${ }^{15}$ Cary, supra note $\mathrm{I}_{3}$, at 49 . See Catlett, supra note Io, at 40 ; Witschey, The Business Need for Better Accounting Principles, J. Accountancy, Jan. 1964, p. 27, at 29.
} 
cumstances begin ? ${ }^{16}$ If alternative methods of accounting for business combinations, recognition of earnings of subsidiaries, pension plan costs, timing of recognition of construction contract income, inclusion or exclusion of nonoperating items from the income statement and other practices have not in all cases been justifiable when viewed in context, ${ }^{17}$ when do differences in circumstances suggest that alternative treatment may have justification in fact? Phrased differently, to what extent can "principles" dictate treatment, and to what extent should flexibility remain with respect to specific types of transactions, within specific industries and under varying circumstances subject to individual value judgments?

Recognizing that greater uniformity is desirable and that movements, whether by way of concept or practice, ${ }^{18}$ towards uniformity, however defined, should be accelerated ${ }^{19}$ through efforts of the accounting profession rather than governmental fiat, ${ }^{20}$ "uniformity of accounting principles" remains a slippery term defying precise limits. For our purposes we can only suggest that it be considered in the context of the effect of a narrowing of alternative procedures.

A final prefatory note would suggest recognizing that much of the impetus toward greater uniformity stems from a desire for a more meaningful basis of comparison of financial data of different companies. ${ }^{21}$ The lawyer faces similar problems in utilizing comparisons for such purposes as valuation of stock of a closely-held company for succession tax purposes and estate planning at an earlier stage, for purposes of buy-sell agreements, and in effectuating business combinations; and he knows that a vital factor in prescription of accounting methods for public utilities lies in the need for comparable data in regulating rates of the several companies. Even in this context, however, uniformity alone will not supply all of the ingredients. For example, selection of a single method, such as straight-line depreciation or LIFO inventories, without recognition of the implications of price-level changes, is only a halfway house. And subjective factors, scarcely capable of uniform portrayal and transcending current patterns of recording financial data, will continue to be of critical importance. Thus greater uniformity may be of assistance, but it falls far short of removing current challenges in the areas of comparison of companies.

Comparability problems, moreover, form a relatively small proportion of the occasions on which the lawyer resorts to accounting data and terminology. Far more often, his task is that of drafting to effectuate the intent of parties to a private

\footnotetext{
${ }^{10}$ Witschey, supra note 15 , at 29.

${ }^{17}$ The examples are from Catlett, supra note Io, at 4I. See also the illustrations set forth by Fox, supra note II, at 44 .

${ }^{18}$ See Storey, stipra note 2, at 52-53, critiquing the historical development of principles and the relative desirability of ad hoc development by practice as distinguished from over-all devclopment of concepts.

${ }^{10}$ Cary, supra note 13 , at 50. Views vary as to the speed necessary. Compare Anthony, supra note 3, at xo6, with Powell, supra note xo, at 43 .

${ }^{20}$ Cary, supra note 13, at 49; Catlett, supra note 10, at 38. Cf. Anthony, supra note 3, at 101-02, I05.

${ }^{21}$ See Fox, supra note II, at 46 .
} 
agreement or working with regulatory agencies and legislation where the goal is effectuation of a particular public policy. Here, too, the degree of potential advantage from greater uniformity varies with the type of legal setting. At one level the task of a court in resolving controversies stemming from documents prescribing a result "in accordance with generally accepted accounting principles" would be eased by a narrowing of acceptable practices. ${ }^{22}$ Similarly, the task of the lawyer might be simplified if increased uniformity permitted less specification than is presently required by the wide variety of alternative methods. Yet the draftsman's task is to effectuate a particular intent, and this may require specification of a method of ascertaining the financial benchmark differing from that which accepted accounting principles might suggest in the normal context of portraying results for management or investors. Thus, a measure of uniformity of accounting principles, while helpful in illustrating the accoutant's approach to an appropriate determination of income or cost, cannot supersede the necessity of drafting an appropriate specification of method to effectuate the posited goal of statutes or regulations, in the light of administrative convenience, or the intent of parties to a private agreement.

The general visceral conclusions structured thus far ought to be examined in the light of the decisions, legislation, materials from the regulatory agencies, and an analysis of the many areas in which accounting terminology and practices have arisen in the lawyer's practice. Studies of this type have been made. ${ }^{23}$ Within the confines of a short essay, only a few examples are possible, but perhaps the suggestions as to the relative utility of minimization of the present lack of uniformity may be illustrated by a cursory look at some aspects of drafting in general practice, a few of the facets encountered in a more sophisticated corporate setting, and, finally, a brief consideration of the implications of uniformity in an area calling for highly subjective determinations, such as cost justification under the Robinson-Patman Act.

II

\section{Some Possible Practical Benefits of Uniformity}

\section{A. Drafting in General Practice}

Frequently the lawyer in general practice has occasion to draft a will or trust providing for payment of income to one beneficiary for life with the remainder interest in the property to pass to another. On occasion, he may be requested to draft an agreement calling for payments keyed to a determination of the income of a business or to the cost of manufacturing an item. The "bonus" agreement with

\footnotetext{
${ }^{22} \mathrm{~A}$ court, faced with interpretation of an agreement, seeks to effectuate the precise language of the agreement. If "generally accepted principles of accounting" are specified, the task generally is limited to choice of the appropriate alternative from surrounding circumstances, such as prior patterns. Absent such specifications the search for intent will focus on accounting principles only to the extent that ambiguity and lack of other ascertainable intent suggests appropriateness of a particular accounting method.

${ }^{23}$ See note 45 infra.
} 
an employee or the percentage lease, calling for a percentage of "net income," and the cost-plus contract are illustrative.

The prime task facing the lawyer-draftsman is the preparation of a document that will clearly express the intention of the client. In the trust setting, a simple direction to pay the "income" to the life tenant may create significant problems for the fiduciary charged with making an appropriate apportionment of receipts between principal and income. However, apart from recognition of potential definitional problems, the draftsman's concern is not with the range of accounting treatment or the acceptability of such treatment in interpretative problems; his task is the minimization of controversy through adequate specification of the meaning of the term in the document at hand, assuming there are no legal restrictions on the goal sought. ${ }^{24}$ Similar considerations apply in the contractual context. ${ }^{25}$ Yet, human limitations being what they are, it may be expected that legal documents will not always contain appropriate specification of the handling of all items determinative of income or cost, and courts may be called upon to ascertain the appropriate formula for income or cost determination. What then of the implications of lack of uniformity and of any movement toward narrowing the range of accepted accounting principles as it affects (a) the draftsman's task and (b) the determination of conflict over ambiguous language?

\section{Trust Problems}

Consider, for example, a trust that owns and has leased out a building, the "income" being distributable to a life tenant. Shall an allowance for depreciation be deducted and shall rents be apportioned on an accrual basis in ascertaining income? It may be helpful to recall that trust law doctrine antedates the remarkable growth of the accounting profession and the increased reliance upon it which this century has witnessed. Influenced by property law concepts, it was early held that rents were not apportionable but accrued at a specific time; ${ }^{26}$ and, in similar vein, it was not surprising that courts at an early date held that no provision for depreciation should be made, ${ }^{27}$ the usual case involving a devise of the dwelling or farm property to the use of a beneficiary for life. Whether based upon an implication of the intent

\footnotetext{
${ }^{24}$ While the fiduciary may be granted broad discretion to determine principal and income allocations, a potential for conflict between the respective beneficiaries suggests that such a power will not be avidly sought by the fiduciary and may prove less useful than specific treatment of foreseeable problems.

${ }^{25}$ For discussion of potential problems arising from the usual provision in an employee's incentive compensation plan that the computation be "made by the corporation's regular public accountants, that they shall follow accepted accounting practice . . . and that their determinations shall bind . . .," sec I Grorge T. Washington \& V. Hensy Rothschild, Compensating the Corporate Executive 88 (3d cd. I962), pointing out that this may be, in reality, merely an arbitration agreement.

${ }^{20}$ See, e.g., 3 Scorr, Trusts $\$ 235$, at 1796-99 (2d ed. 1956). Views change, however; $\$ 4$ of the Revised UNiform Principal and INCOME ACT, in 9B UNIForm LAws ANN. 180 (Supp. 1964), does make some provision for apportionment.

${ }^{27}$ See, e.g., 3 Scort, Trusts $\$ 239.4$ (2d ed. 1956).
} 
of the settlor to favor the life beneficiary ${ }^{28}$ or recognition of the tendency of real estate to appreciate in value ${ }^{29}$ with a consequent preservation intact of the initial dollar value of corpus, the doctrine developed that the trustee was under no obligation to set up a provision for depreciation. And it seems probable that trustees themselves gave little thought to the problem, assuming that they had neither the duty nor the right to provide a reserve for depreciation absent a specific direction in the instrument. ${ }^{30}$ With an increasing awareness of accounting treatment and with the emergence of trusts containing commercial rental buildings and businesses where the testator himself had recognized depreciation in his financial records, it was not surprising to find courts questioning the validity of a general prohibition against a provision for depreciation. ${ }^{31}$ Yet previously developed doctrines tend to be modified in slow stages, and it may still be said that "in the absence of a provision authorizing the trustee to set up reserves, there is doubt in a great many jurisdictions of his power to do so,"32 and the rules do, and should, depend upon the particular circumstances. $^{33}$ Thus general acceptance by the accounting profession of the necessity for periodic provision for depreciation of buildings has not resulted in universal acceptance of the principle in legal determinations of trust income, though its effect has been felt in both the case law and in the development of statutes governing allocation of income absent specification by the settlor. ${ }^{34}$

Even if the draftsman provided that income is to be determined "in accordance with generally accepted accounting principles," some could find residual ambiguity as to whether this referred to accounting principles in the normal commercial setting or those applied generally in trust accounting. If he specifically provided that provision be made for depreciation, the problem remains as to whether straight-line or some form of accelerated depreciation is appropriate. Additional problems may arise. If accelerated depreciation is utilized for income tax purposes but straight-line amortization is deemed appropriate for trust accounting purposes, shall an adjustment be made for the shift in tax impact? The accelerated depreciation might have reduced the income tax liability of the life tenant while reducing the tax basis of the assets and thus creating a potentially greater tax burden for the remainderman upon sale or with respect to depreciation in later years when he comes into possession. ${ }^{\mathbf{3 5}}$ Similar problems could arise where depreciation is taken only for tax purposes and not for

\footnotetext{
${ }^{38}$ See, e.g., James P. Johnson, A Draftsman's Handbook for Wilis and Trust Agreements 466-67 (г961); Capron, Reserves Against the Depreciation of Real Property Held by a Trustee, I2 OHio ST. L.J. $565,569-70$ (I95I).

${ }_{30} 3$ SCOTT, TRUSTS $\$ 239.4$, at 1870 (2d ed. I956).

${ }^{30}$ Capron, supra note 28 , at 565 .

${ }^{31}$ E.g., Matter of Kaplan, I95 Misc. 132, 88 N.Y.S.2d 85 I (Surr. Ct. 1949).

${ }^{32}$ Gilbert T. Stephenson, Drafting Wills and Trust Agreements 4 I9 (I952).

${ }^{33} 3$ Scort, Trusts $\$ 239.4$, at 1874 (2d ed. 1956 ).

34 E.g., Fla. Stat. ANn. $\$ 691.03$ (I4) (I944); Revised UNiform Principal and Income ACt $\S \mathrm{I}_{3}(\mathrm{a})(2)$, in $9 \mathrm{~B}$ UnIform LAws ANN. I85 (Supp. $\mathrm{r}_{964}$ ).

${ }^{36}$ For an illustration of this type of problem, see Estate of Rice, 8 Pa. D. \& C.2d 379 (Orphans' Ct. 1956).
} 
trust purposes. In view of the increasing attention being given by accountants to the effect of price-level changes, it is possible to foresee future claims that appropriate adjustment be made rather than matching depreciation expressed in "old dollars" against rental receipts in the form of current dollars. ${ }^{36}$ Perhaps it is even within the realm of speculation that a continued emphasis on re-examination of the realization principle ${ }^{57}$ and a renewed emphasis on accounting for value, ${ }^{38}$ accompanied by new techniques, could once more suggest maintenance of intact value of $\operatorname{corpus}^{30}$ (with appropriate price-level adjustments) as an appropriate goal.

The point to be noted is that the draftsman's task is to ascertain the client's intent and then, where depreciation is called for, specifically to direct recognition of depreciation, the method to be used, and whether adjustment is called for where tax determinations differ from the specified method. Uniformity, or a narrowing of acceptable methods, thus furnishes no solution for the lawyer who must effectuate intent even if it differs from an accepted accounting principle. Only if generally accepted accounting principles give a single clear answer (and not alternatives) in accord with the ascertained intent of the client, can narrowing of alternatives be of assistance, though limited, by permitting a drafting short-cut through incorporation by reference of generally accepted accounting principles.

Where the problem has proceeded to litigation over the meaning of terminology, the court's focus will also be on "intent" and only where this is deemed to refer to generally accepted accounting principles is a narrowing of alternatives likely to be of assistance. ${ }^{40}$

Recent legislation designed to minimize future litigation by setting forth the appropriate method of determining income in the absence of specific provision by the draftsman does suggest possible benefits from a narrowing of alternatives that can be accommodated within the act's references to "generally accepted accounting principles." ${ }^{\text {II }}$ Yet, if any such modification occurs, there surely ought to be re-

\footnotetext{
${ }^{36}$ Staff of the Accounting Research Division, AICPA, Reporting the Financial Effects on Price-Level Changes (Accounting Research Study No. 6, 1963 ). "[T] he [Accounting Principles] Board -. agreed that the assumption in accounting that fluctuations in the value of the dollar may be ignored

${ }^{37}$ See generally Robert T. Sprouse \& Maurice Moonitz, A Tentative Set of Broad Accountino Principles for Business ENTERPrises (AICPA Accounting Rescarch Study No. 3, 1962).

${ }^{38}$ Ross, The Crucial Importance of Valuation in Accounting, J. Accountancy, Oct. 1964, p. 68.

so The concept was of importance under various aspects of the "Pennsylvania rule" for apportionment of dividends received by the trust. See, e.g., Note, 36 Iown L. REv. 543, 545-56 (I95I).

${ }^{10}$ For example, assume that a contractor left his business in trust. Alternative methods of accounting (recognizing income based upon the percentage of completion method or conversely only upon completion of the contract) could yield significantly different determinations of "income" during a beneficiary's period of entitlement. Even assuming that accounting principles could be narrowed to selection of one method as appropriate for purposes of the profession, a court could hardly be criticized for looking to the method actually followed by the settlor, in ascertaining "intent," although it might not be in accord with generally accepted accounting principles.

${ }^{1}$ E.g., Revised Uniform Principal and Income Act $\$ \$ 8,13(a)(2)$, in $9 B$ Uniform Laws Ann. I82, 185 (Supp. I964). Discussion in this article has been limited to depreciation, but obviously a wide variety of principal and income problems confront the lawyer and present similar considerations. The act itself is illustrative, though not inclusive.
} 
examination of the legislation to ascertain whether the remaining principle is appropriate in the light of the legislative goal.

In the final analysis, any movement to narrow the range of alternative treatment may furnish some guidance as to what is appropriate in a general context, but it cannot supplant the duty of the draftsman or the court to provide an appropriate standard in the legal context in line with the expressed or implied intent of the involved parties.

\section{Problems in a Commercial Setting}

Would the consideration of problems inherent in lack of uniformity and the related question of the effect of a narrowing of accepted alternatives be different where drafting is required in a commercial setting less encrusted with historically derived precedent? An illustration may be useful. Assume that an employment agreement provides for a bonus of ten per cent of all "net income" in excess of a specified amount. ${ }^{42}$ Absent further specification, the determination of the appropriate bonus at the end of the first year of operations of the newly organized business poses myriad possibilities for disagreement. Even the specification of use of "generally accepted accounting principles" leaves an area for dispute as broad as the long list of alternative accepted methods set forth in Accounting Research Study No. $7{ }^{43}$ For example, choice of inventory method, of straight-line or some method of accelerated depreciation, of depletion method, of a method for handling research and development costs, of timing recognition of income (in terms of the alternatives of sale, collection or completion of the product, and, in the context of long-term contracts, in terms of percentage of completion or a completed contract method), of handling pension plan costs and cash discounts, and a host of other alternatives could significantly affect the "income" of the period. So, too, in other years, might decisions with respect to handling of extraordinary items, such as treatment of gains as an item includible in an all-inclusive income statement or by a direct credit to surplus,

is unrealistic ...." Id. at I (quoting the Board's minutes). This Accounting Research Study examines the problem in depth and collects, in an extensive bibliography, many of the valuable earlier writings.

: A somewhat more complex formula providing for a bonus of $10 \%$ of net earnings after deduction of a "cost of capital" computed on " $6 \%$ of capital employed in the business" could present the type of problems involved in Winkelman v. General Motors Corp., 44 F. Supp. 960 (S.D.N.Y. I942). There the court held that dividends declared on treasury shares were properly included in "capital employed," that profit on resale of treasury shares was not an income item properly reflected in earned surplus (in accord with current accounting treatment), and struggled with such questions as whether interim earnings during the period were a part of "capital employed," the appropriate treatment of asset revaluation, and the further problem of whether the bonus was itself to be considered in arriving at net income or was to be based upon net income without consideration of the resulting bonus. For discussion of the case and generally for discussion of the types of problems that may be encountered, see 2 Washingron \& RorHschiLd, op cit. supra note 25, at 893-903; Birnbaum, Corporate Accounting Problems, 36 Iowa L. REv. 286, 290-94 (I95I).

${ }^{3}$ Paul Grady, Inventory of Generally Accepted Accounting Principles for Business EnterPRISES 373-79 (AICPA Accounting Research Study No. 7, 1965) (set forth in Appendix $D$ at the end of this symposium). See also Powell, supra note zo. 
treatment of the investment credit as an item to be spread over the life of the acquired assets or to be taken in a single year, handling of self-insurance reserves, "lease versus purchase" arrangements, and amortization of intangibles. Other items affecting determination in a large corporation might include choice of method with respect to nonconsolidated subsidiaries, principles of consolidation, stock options, business combinations, and others.

Despite differences in setting and in the complexity and range of problems presented, the role of generally accepted accounting principles and the effect of an attempt to narrow the range of acceptable alternatives in the area of drafting commercial agreements suggests considerations similar to those mentioned in connection with the drafting of trust provisions. Initially the burden is upon the draftsman to ascertain the intent of the parties and to express it as unambiguously as possible, a task requiring an appreciation of the type of interpretative question that may arise from particular language employed. Where uncertainty remains, it may be the result of alternative accepted accounting principles or of the existence of a type of problem inherent in the particular language and as to which accounting principles would give little guidance (such as whether the bonus was itself deductible in arriving at "net income" within the meaning of the term as used by the parties). ${ }^{44}$ Resolution of the meaning of ambivalent terms will still require a search for the subjective intent under the particular circumstances, though ultimate resort to accounting principles in this context is less inhibited by any deference to prior legal doctrine such as that encountered in interpretation of trust instruments.

Here again a narrowing of accepted principles can only ease the draftsman's task where the intent to be expressed can be framed in terms of reference to accepted principles, though the narrowing may facilitate the task of resolving ambiguity by a court that finds reference to general accounting principles useful in arriving at an appropriate interpretation of the terminology used. ${ }^{45}$

\section{B. Corporate Practice}

The lawyer's activity in advising his corporate client suggests, in similar vein, differing potential effects from a narrowing of alternative accounting practices. Again, the spectrum results from variations in the degree to which the emphasis is on factors peculiar to the particular problem rather than on reliance on accounting practices. Even where accounting practices are the determinant, the existence of subjective criteria deemed desirable for an appropriate choice of method for fair presentation suggests limitations on the potential effect of a trend toward greater uniformity.

\footnotetext{
1 See note 42 supra.

${ }^{15}$ Some have undertaken an analysis of the reaction of courts to accounting principles. Sec Gronor S. Hills, The Law of Accounting and Financiar Statements \$§ 1.3-.10 (1957); Simon, Hosv Far Do the Courts Go in Upholding Accounting Principles for Determining Income?, $94 \mathrm{~J}$. Accountancy 683 (I953).
} 
$A$ very brief look at the areas of asset acquisition, corporate combinations, and dividend restrictions may furnish convenient, if inadequate, illustrations.

\section{Recording of Value of Acquired Assets}

For example, appropriate accounting treatment normally requires the recordation of property acquired, whether for cash or securities, at cost. While reference to the "true value" rule may still be found, the more commonly encountered approach is the setting of value based upon the determination of the corporate directors subject only to the requirement of "good faith." Clearly the determination may have a significant effect on a host of future financial determinations, such as the ascertainment of "income" of various years, resultant "retained earnings," and the like. Yet it is equally clear that this is an area in which "uniformity," in so far as it relates to an appraisal of actual value at the time of acquisition, plays little or no role.

\section{Accounting for Corporate Combinations}

As an illustration of an area where alternative accounting practices are directly involved and a single choice between competing alternatives is called for, consider the combination of two or more previously independent corporations, whether characterized as a merger, consolidation, or by some other term, and whether resulting in survival of one firm or the creation of a new entity. Accountants might agree that appropriate accounting treatment should depend not on the legal characterization but rather on the extent to which the change is merely a matter of form, i.e., on whether the transaction is one "in which the holders of substantially all of the ownership interests in the constituent corporations become the owners of a single corporation which owns the assets and businesses of the constituent corporations," of the previously existing ownership group of one or more of the combining entities is eliminated or in which there has been a change in management. In the former case, the "pooling of interests" in which the change is deemed largely one of form, accounting theory has suggested that

a new basis of accountability does not arise. The carrying amounts of the assets of the constituent corporations, if stated in conformity with generally accepted accounting principles and appropriately adjusted when deemed necessary to place them on a uniform accounting basis, should be carried forward; and the com-

\footnotetext{
${ }^{10}$ Corporate lawyers have long struggled with the problem of appropriate limitations on the value to be recorded for assets acquired by issuance of securities and the cases are legion involving "watered," "bonus," and "discount" shares, though the incidence of such problems is less frequent than in earlier days. While instances of the "true value" test, involving the question of whether the property was really "worth" the stated value of the stock, may still be found, the usual criteria is "good faith." See, e.g., Ralph J. Baker \& Williak L. Cary, Corporations 740-43, 778-79 (3d ed. abridg. I959).

17 Comaittee on Accounting Procedure, Aicpa, Business Combinations 22 (Accounting Research Bull. No. 48, r957).
} 
bined earned surpluses and deficits, if any, of the constituent corporations should be carried forward, except to the extent otherwise required by law .... 48

On the other hand, if the requisite basis for a "pooling of interests" is not found, accountants would generally agree ${ }^{49}$ that the acquisition should be characterized as a "purchase" with a resultant change in the recorded valuation of the assets acquired ("book value" of the transferor being supplanted by recordation at "cost" on the books of the transferee).

While it is clear that the method utilized may have a significant impact on both the level of "income" reflected in future statements and on the "retained earnings" of the combined entity, precise uniformity is not a reasonable expectation at the present time. ${ }^{50}$ Further, as Accounting Research Bulletin No. $4^{8}$ makes perfectly clear, no magic formula exists for translating the general concept into precise rules carefully delineating application to the wide variety of conditions that might be encountered in a complex modern corporate combination. ${ }^{51}$ While factors may be suggested as indicative of a pooling of interests, such as continuity of management, voting rights, control, former ownership, similarity of business operations and relative size, even such general criteria (for example, relative size) have not been consistently followed in practice. ${ }^{52}$ And because the question involves a basic value judgment in the light of a myriad variety of attendant circumstances, some will surely feel that any attempt at further specification and rigidification in the interest of uniformity, at the expense of unimpeded value judgment formulated in the light of the general theory, would be unwise.

\section{Dividend Restrictions}

As a final example, the corporate problem may involve a determination affected by a large number of the instances in which alternative practices are found. One such area involves counseling with respect to dividend restrictions.

Occasionally, the lawyer may be asked to give an opinion on the legality of a proposed dividend in the light of the governing corporation statute. Whether the focus of the statute ${ }^{53}$ is on a requirement of some form of surplus or upon a "nimble

\footnotetext{
${ }^{48}$ Id. at 24. See also H. A. Finney \& Herbert E. Miller, Principles of Accounting-InterMEDIATE 594-95 (5th ed. 1958).

10 FINNEY \& MILLER, Op. cit. supra note 48 , at 594 .

${ }^{\circ}$ Some accountants have found difficulty with the idea that retained earnings may be transferred in connection with a combination, even though they might accept the distinction between the "purchase" and "pooling of interests" for the purpose of asset recordation and even though "retained carnings" of the newly combined entity can never exceed (though they might be less than) the aggregate of the formerly existing companies. Sce FinNeY \& MilleR, op. cit. supra note 48 , at 595-96.

${ }^{61}$ Committee on Accounting Procedure, op. cit. sipra note 47, at 25.

62 Id. at 26 .

${ }^{53}$ In grouping the statutes, Kehl's traditional dichotomy focused on a "balance shect test" as distinguished from an "earned surplus test." Donald KeHL, Corporate Dividends 26 (I94I). Hills suggests that "in general, state corporation laws recognize three sources of funds for the payment of dividends: (a) retained earnings, or earned surplus; (b) surplus (defined as the excess of net assets over stated
} 
dividend" approach, ${ }^{54}$ it is readily apparent that the choice of accounting methods has a significant effect on both the "surplus" and the "net income" items, including the timing of income recognition. The statement that "the more recent enactments are intended to embody generally accepted principles of accounting"55 may suggest a desirable reliance on the accounting art, but it remains clear that a permissible selection of alternative "generally accepted accounting principles" consistently applied and deemed appropriate in the circumstances could result in quite different measures of limitation of dividends for two corporations alike in all respects except accounting methods.

In counseling with an individual client, the lawyer's concern is not with uniformity but with ascertaining what may be done within the ambit of existing accepted practices and with the effect in terms of the statutes. In broader context, however, his concern is with a statute that treats similar corporations in differing ways dependent only on choice of accounting methods. Awareness of permissible differences might suggest the inappropriateness of a legal benchmark varying with choice of accepted, but alternative, methods and suggest greater specificity; and some modern statutes do expressly deal with particular accounting problems. ${ }^{56}$ Yet, again, encompassing statutory specificity seems a dubious goal in the light of the multiplicity of circumstances that the general statute must govern. Clearly, a narrowing of the acceptable alternatives would tend to alleviate disparity and enhance the utility of accounting terms in corporate statutes. ${ }^{57}$ But, again, the lawyer will recognize that in some areas subjective factors suggest that uniformity may only proceed to the point of identifying criteria that should affect the choice of alternatives while in others elimination of presently existing alternatives may be accomplished without

capital) including unearned surplus, such as paid-in surplus, revaluation surplus, and reduction surplus; and (c) . . . net earnings for a specified period such as the current and next preceding fiscal year." HrLls, op. cit. supra note 45, at 159-61. (Footnotes omitted.) See De Capriles, Modern Financial Accounting-Part II, 38 N.Y.U.L. REv. $1,24-35$ ( 1963 ), for a discussion of permissible dividends and particularly the "wasting assets" approach, at 28-29. Under any grouping, the effects of alternative accounting methods on each type of dividend statute is apparent.

"For a discussion of "nimble dividends," dividends paid out of net income of a specific period in spite of an existing impairment of capital, see, e.g., Baker \& CARY, CoRporations Ioo6-I2 (3d ed. abridg. 1959); De Capriles, supra note 53, at 34-35; Kreidmann, Dividends-Changing Patterns, 57 Colum L. REv. 372 passim (1957); McCormick, Nimble Dividends: Some States Do Permit Dividends Despite Deficit in Accumulated Earnings, $88 \mathrm{~J}$. Accountancy 196 (1949).

${ }^{50}$ Hills, op. cit. supra note 45 , at 163 .

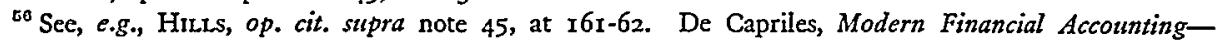
Part I, 37 N.Y.U.L. Rev. IooI n.3 (I962), commenting on post-I945 corporation statutes, suggests, "The revised statutes generally feature greater precision than their predecessors in their accounting and financial provisions."

E7 "Practicing lawyers generally have not favored expanded use of accounting terms and concepts in the corporation laws on the ground that these terms and concepts are not sufficiently precise. Aside from the implied, and probably unwarranted, assumption that 'legal' terms and concepts are necessarily preferable in dealing with such matters as legal capital and surplus, this view seems to be basically unjustified. A large segment of the legal profession seems to be unaware of the tremendous progress toward theoretical synthesis that has been made by the accounting profession."

De Capriles, Modern Financial Accounting-Part II, $3^{8}$ N.Y.U.L. REv. I, 66 (1963). 
significantly jeopardizing fairness of presentation and resultant enhancement of comparability of treatment. ${ }^{58}$

Far more commonly, the lawyer's concern with dividend limitations arises in connection with consensual arrangements, such as contractual restrictions incident to credit negotiations or defining the rights of preferred shareholders. While a narrowing of accepted alternatives might ease the task of the draftsman, his effort must be directed toward preparation of an effectively descriptive instrument, in the light of the purposes of the parties and the circumstances of the particular corporation; and his concern is with an appropriate specification of the method of determining financial benchmarks rather than with uniformity as such.

\section{Conclusions}

In sum, then, lack of uniformity may cause disparity in application of statutory benchmarks applicable to different corporations and does suggest the need for careful drafting by the lawyer in effectuating a contractual arrangement. An increase in uniformity should prove helpful in the former case and might ease the draftsman's task in the latter. In each instance, however, effectuation of the intent of the particular legislation or agreement may suggest subordination of a "generally accepted" uniform accounting method to specification of methods peculiarly appropriate to the draftman's goal.

\section{Cost Justification Under the Robinson-Patman Act}

A far more esoteric area of contact between law, accounting, and economics is found in the Robinson-Patman Act ${ }^{59}$ area, particularly as it relates to utilization of the cost-justification proviso of section 2(a) that "nothing herein contained shall prevent differentials which make only due allowance for differences in the cost of manufacture, sale, or delivery resulting from the differing methods or quantities in which such commodities are to such purchasers sold or delivered ...."."00

As Rowe has noted, "the process of cost allocation is accountancy in its purest yet most subjective and intuitive form," "proof of a cost justification being what it is, too often no one can ascertain whether a price is cost-justified." ${ }^{\prime 2}$

\footnotetext{
${ }^{68}$ Dividend statutes are only one illustration. Similar problems arise with respect to the purchase and redemption of the corporation's shares. See, e.g., Baker \& CarY, Corporations 1050-53 (3d cd. abridg. x959); De Capriles, Modern Financial Accounting-Part II, 38 N.Y.U.L. REv. 1, 29-30 (1963); Rudolph, Accounting for Treasury Shares Under the Model Business Corporation Act, 73 HAnv. L. REv. 323 (I959).

${ }^{60} 49$ Stat. I526 (I936), I5 U.S.C. $\$ \S I_{3}-\mathrm{I}_{3} b, 2$ Ia $\left(I_{964}\right)$.

${ }^{60}$ Clayton Act $\$ 2(a), 49$ Stat. $1_{526}$ (1936), I5 U.S.C. $\$ 1_{3}(a)(1964)$.

${ }^{61}$ Frederick M. Rowe, Price Discrimination Under the Robinson-Patman Act 290 (1962).

${ }^{02}$ Automatic Canteen Co. of America v. FTC, 346 U.S. 6r, 79 (I953).
} 
For many a lawyer, this has proved a most frustrating area. On the broader base, he quickly recognizes what Rowe refers to as "the nexus between cost and price"; ${ }^{63}$ that is, he realizes that, in a competitive market, price variations are based upon the interaction of economic pressures rather than upon a necessary relationship to cost as such. Further he recognizes that there is a distinct difference between the legal and economic definitions of price justification, the economist's view of cost differentials being far broader than the statutory provision recognizing only differences in cost of "manufacture, sale, or delivery" and utilizing only historic cost factors already realized at the time of the pricing in question. ${ }^{64}$

Within the narrower area of cost justification itself, he knows that accounting records have not been kept, normally, to reflect detailed cost data by products or customers to the degree required by a particular cost justification problem, ${ }^{65}$ either because management feels no need for such detailed information with respect to product and distribution costs, or feels any such attempt is not worth its cost for management purposes, or even, perhaps unconsciously, to avoid any implication of knowing violation under section $3 .^{66}$

Sophistication derived from working with the client's accounting firm quickly convinces the lawyer of the subjective nature of determinations of product costs where joint product, multi-plant, multi-area operations are involved. ${ }^{67}$ And when he resorts to justification based upon delivery price differentials, he soon encounters the difficulties of appropriate customer classification and the problems inherent in determining the viability of post-fact sampling techniques and subjective allocations of costs that cannot be directly related to a particular customer. While his traditional role in this area is that of an advocate, even he may yearn for some measure of guidance as to what is and is not acceptable.

From the point of view of the lawyer and of the company facing potential Robinson-Patman Act investigations, can and should accounting techniques be refined to provide further guidance with a view to restricting areas of controversy? Trade associations have attempted to work out uniform systems of accounts, and legislative efforts have been made to define at least the lower limits of costs for purposes of enforcing minimum sales price acts. It is conceivable that some corporate managements might welcome further delineation in the interests of assurance of cost

\footnotetext{
${ }^{03}$ Rowe, op. cit. supra note $6 \mathrm{I}$, at $3 \mathrm{I}$,

os Id. at 30 .

ot See Advisory Comm. on Cost Justification, Report to the Federal Trade Commission III-C-2 (1956) [hereinafter cited as RePORT to FTC]. It is reprinted in Herbert F. TAgGart, Cost Justification 555-72 (1959).

${ }^{00}$ See Rowe, op. cit. supra note 6I, ch. I5; Comment, 49 Nw. U.L. Rev. 285, 289-92 (1954). See also discussion in Fuchs, The Requirement of Exactness in the Iustification of Price:and Service Differentials Under the Robinson-Patman Act, 30 Texas L. REv. I, IO-II (I95I).

${ }^{\circ 7}$ See Rowe, op, 'cit. supra note 6r, ch. ro; TAGgart, Cost Justification (1959), collecting and analyzing cases.
} 
justification of proposed differentials, though those experienced in this area may well express doubts. Surely the more fundamental question is whether any such effort at great specificity would yield desirable results in view of the nature of the problem that the legislation seeks to handle. There are, of course, avenues of improvement. Some facets of an attempt to narrow the range of permissible accounting methods, such as eliminating the present divergence of methods of handling cash discounts, would have at least minimal impact if agreemeent could be reached. ${ }^{08}$ The Commission may be urged, as was done by the 1956 Report of the Advisory Committee on Cost Justification to the FTC, to endorse certain "general principles concerning proof of an accounting nature to serve as guides," veloping sound methods and procedures of allocation," and to "perform a laudable service by issuing a continuing series of accounting opinions on such matters."70 Yet the Report continually recognizes the peculiarly subjective quality of the analysis necessary in specific cases and that "a method which may be sound under certain circumstances may be unsound under different conditions. Consequently, it would not only be impracticable, but wholly inadvisable, to recommend uniform methods of allocation." 71

Though the type of problem posed may be a bit different from those in other areas noted, the basic ingredients affecting the question of "uniformity" remain the same though the mix varies. The existence of divergent views with respect to appropriate treatment certainly suggests continued study, if only to add dimension and to develop guidelines; and areas will surely be identified in which, on balance, narrowing of choices will seem desirable. Yet the very nature of the accounting problems, involving vastly differing factual settings and a high degree of value judgment, suggests that the purposes of the legislation and the interests of those concerned may perhaps best be served by evolution of guidelines rather than any attempt at rigid specification in the interests of uniformity. ${ }^{72}$

\footnotetext{
${ }^{68}$ See, e.g., H. A. Finney \& Herbert E. Miller, Principles of Accounting-Introductory 7r (6th ed. 1963 ), suggesting that with time it has come to be accepted that the better theory is that purchase discounts are not an item of revenue but a reduction of purchase costs and that sales discounts for prompt payment are in effect a reduction of sales revenue. This is in accord with REPORT To FTC II-B-4, pointing out that the available cash discount lowers the price, whether or not a careless or ill-financed buyer takes advantage of it. In listing alternative methods, Paul Grady recognizes timing differences:

"There are two methods of recording cash discounts. In the first method, the cash discount is recorded as an income deduction only when the customer takes the discount by remitting earlicr. In the second method, the sale is recorded and the customer's account charged for an amount excluding the discount; if his remittance is made after the discount period is over, the discount lost ... is recorded as a gain in that period."

Paul Grady, Inventory of Generally Accepted Accounting Principles for Business Enterprises 77 (AICPA Accounting Research Study No. 7, r965).

${ }^{69}$ REPORT TO FTC III-B.

${ }^{70} \mathrm{Id}$. at III-C-4(e).

${ }^{71}$ Id. at III-C-4.

72 "The Committee believes that any attempt to lay down detailed procedures for all business enterprises or otherwise to strait-jacket cost justification would be self-defeating." Id. at III-C-I.
} 
III

In Brief Conclusion

The attorney may encounter a variety of problems involving the use of accounting terminology and applications. As he acquires familiarity with the range of current practices, he realizes that within the framework of "generally accepted accounting principles" present circumstances may afford a choice between alternative accounting methods yielding differing presentations of financial position and results of operations.

Where the task involves comparability of several companies, the attorney, like other members of the public, is disturbed by the fact that alternative practices may occasion differing statements of costs, income, and financial position, with resultant difficulties if comparison or comparable treatment of the companies is desired. Herein lies the greatest impetus toward minimizing lack of uniformity.

Problems inherent in comparability are, however, of relatively less importance to the lawyer than to the investor; far more frequently the lawyer's concern with accounting terminology and practices is centered on the financial data of a particular business entity in the context of drafting an appropriate agreement or resolving a dispute involving financial determinations. Here, a narrowing of alternatives consistent with the accountant's goal of "fair presentation," useful as it may be for purposes of comparability, may have a more limited effect.

In the area of private agreements, greater uniformity may facilitate the draftsman's task; yet it cannot relieve him of the responsibility of ascertaining the intent of the client and, in an appropriate manner, expressing that intent whether it accords with an appropriate uniform practice or requires specific departure for purposes of the specific agreement. A departure from accounting principles may also be expected, despite a narrowing of alternative practices, where the particular purpose of legislative or regulatory prescription appears to require treatment varying from that deemed preferable for the fair presentation of financial data to management or investors.

Nevertheless, though differences will occur, the ability of the accounting profession to reach agreement in critical areas on the appropriate treatment of specific items should influence future drafting. The re-examination and narrowing of choices should suggest a careful consideration of whether, in the light of the accounting profession's reasoned choice, there is sufficient justification for departure in the interest of the specific purpose to be effectuated by the draftsman. Surely in some cases it will be found that the accountant's choice has a sufficiently convincing rationale to justify its use in the particular legal context or, at least, can be accommodated within the framework of the purpose to be achieved when the advantages of parallel treatment are weighed against factors suggesting a departure from the accepted accounting practice. 
From an over-all viewpoint, then, whether the context be comparison, drafting, or resolution of controversy, a narrowing of acceptable alternatives should be useful, though in varying degrees. Yet the lawyer will recognize, as does the accountant, that a consideration of "uniformity" requires distinguishing between variations in accounting treatment resting on factual differences and, on the other hand, a free choice of alternative permissible methods under the same factual circumstances. ${ }^{73}$ If the accountant's goal is "fair presentation" of financial data, there is surely a need for flexibility to choose the most appropriate method; thus, the thrust of this aspect of reform may be expected to be directed toward limiting variations in treatment to those that may be justified by differences in factual setting, accompanied by some identification of the criteria that justify the variations. Even a narrowing of currently existing alternatives applied in the same circumstances presents a formidable challenge, particularly where the choice between present firmly entrenched alternatives is difficult, may have regulatory and tax implications, and requires a departure from practices that have been consistently followed by a particular client in the past.

In broader perspective, the legal profession has a vital interest in the multiple aspects of current ferment within the accounting profession; ${ }^{74}$ indeed, a re-examination of basic premises, and progress in such areas as accounting for price-level changes, have implications of potentially greater significance than the related effort to narrow the range of presently accepted alternative procedures. By virtue of its own experience with efforts of codification and restatement, the profession is in a unique position to recognize the types of problems and competing considerations inherent in achieving either philosophical agreement on basic postulates or in the more specific task of narrowing the range of acceptable alternative practices, while maintaining an appropriate accommodation of the degree of flexibility essential to maximum effectiveness in a complex and dynamic institutional setting. This should suggest to the legal profession both a sympathetic awareness of the problems and choices with which the accounting profession must grapple and a continuing recognition of the need for a sophisticated familiarity with the current state of accounting practice that is essential to effective counseling and drafting when financial determinations arise in a legal context.

\footnotetext{
${ }^{73}$ See Specinl Comm. on Opinions of the Accounting Principles Bonkd, AiCPA, Repont i6 (1965).

"In recognition of this interest, "the Accounting Principles Board of the American Institute of Certified Public Accountants has agreed to submit all accounting principles studies and proposed pronouncements to the pertinent sections of the American Bar Association .... in order that all interested groups may comment upon the contents thereof, insofar as legal concepts are concerned." Letter from Arthur J. Levy, Chairman of the ABA Special Committee on Professional Relations, to the author, Oct. 7, 1965.
} 